\title{
Floristic Composition and Community Analysis of Berbere Forest, Bale Zone, South East Ethiopia
}

\author{
Tesfaye Bogale ${ }^{1, *}$, Demeke Datiko ${ }^{2}$, Shiferaw Belachew ${ }^{3}$ \\ ${ }^{1}$ Ethiopian Biodiversity Institute (EBI), Mettu Biodiversity Center, Mettu, Ethiopia \\ ${ }^{2}$ Ethiopian Biodiversity Institute (EBI), Hawassa Biodiversity Center, Hawassa, Ethiopia \\ ${ }^{3}$ Biology Department, College of Natural Science, Madda Walabu University, Robe, Ethiopia
}

\section{Email address:}

tesfukiyya@gmail.com (T. Bogale), datikodeme@yahoo.com (D. Datiko), s32799@gamil.com (S. Belachew)

${ }^{*}$ Corresponding author

\section{To cite this article:}

Tesfaye Bogale, Demeke Datiko, Shiferaw Belachew. Floristic Composition and Community Analysis of Berbere Forest, Bale Zone, South East Ethiopia. Agriculture, Forestry and Fisheries. Vol. 6, No. 6, 2017, pp. 206-213. doi: 10.11648/j.aff.20170606.14

Received: August 26, 2017; Accepted: September 30, 2017; Published: November 10, 2017

\begin{abstract}
The study was conducted on Berbere forest in Bale Zone of Oromia National Regional State, South east of Ethiopia with the objective of determining the floristic composition and community type of the forest. Systematic sampling method was used to collect vegetation data. Seventy two quadrat size of $400 \mathrm{~m}^{2}(20 \mathrm{~m}$ x $20 \mathrm{~m}$ ) for trees, shrubs and lianas and five $1 \mathrm{~m}^{2}(1 \mathrm{~m} \mathrm{x} 1 \mathrm{~m})$ for herbs one at each corner and one at the center of the main plot were used. In each of these quadrants, all vascular plant species were collected and brought to National Herbarium, Addis Ababa University for identification. Vegetation classification was performed using PC-ORD software packages. Sorensens's similarity coefficient and ShannonWiener diversity index were also used to detect similarities among communities and to compute species richness and evenness between the plant communities' respectively. A total of two hundred one plant species in 157 genera and 65 families were identified from the forest. Fabaceae and Asteraceae are the dominant families in terms of species richness. Based on the results of vegetation classification, three plant communities (Terminalia brownie-Psydrax schimperiana, Warburgia ugandensis Podocarpus falcatus, and Euclea racemosa subsp. schimperi-Combretum molle) were recognized and described. Ethnobotanical studies to explore indigenous knowledge on the diverse uses of plants, and sound management and monitoring as well as maintenance of biodiversity that promote sustainable use of the forest and its products are recommended.
\end{abstract}

Keywords: Bale Zone, Berbere Forest, Plant Community, Species Diversity

\section{Introduction}

Ethiopia has diverse macro- and micro- climatic conditions that have contributed to the formation of diverse ecosystems which helped for the evolution and survival of biodiversity ([8], [22], [38]). As the result, Ethiopia hosts the fifth largest floral diversity in tropical Africa ([12]). In addition the biological diversity is extremely complex due to its wide ranges of altitude, its great geographical diversity with high and rugged mountains, flat-topped plateaus and deep gorges, incised river valleys and rolling plains ([22], [38]). Sadly, biodiversity resource and their habitats are under extreme pressure from human induced factors like agricultural land expansions, illegal settlement, timber harvesting, firewood collection, charcoal production and overgrazing ([30], [31],
[33], [39]). This might be due to negligence of local community knowledge on sustainable utilization of biological resource and lack of availability of optional resource for their livelihood needs.

The Bale Eco-Region harbours diverse and unique biodiversity resources at ecosystem and species level. The Bale eco-region belongs to the Eastern Afromontane biodiversity hotspot, which is one of the 35 biodiversity hotspots worldwide due to its exceptionally high levels of biodiversity and threats ([37]). It comprises about twelve vegetation ecosystems each of which can further be subdivided into plant communities. The vegetation ecosystems include: Afro-alpine grassland, Erica forest/shrubl and, 
Mountain grassland, Dry Afromontane evergreen forest, Moist Afromontane evergreen forest, Bamboo forest, Combretum-terminalia woodland, Acacia-commiphora woodland, and Wetland. Berbere forest is in the southeast of Ethiopia, Bale zone in Berbere woreda. Therefore, generation of scientific knowledge through the studies of floristic composition and species diversity could be one of the intervention mechanisms to contribute towards the conservation of vegetation resources and the associated biodiversity. In addition, knowledge of floristic composition and diversity of of forest is also valuble in identifying ecologically and economically important plants and their diversities, protecting threatened and economical important plants species ([2]). The objective of this study was to determine and document the floristic composition and classify the forest vegetation into plant community types of Berbere forest.

\section{Materials and Methods}

Study area: Berbere forest is administratively located in Berbere district, Bale zone, Oromia National Regional State, and $530 \mathrm{~km}$ from Addis Ababa and $100 \mathrm{~km}$ from capital of Bale zone, Robe. The study area is located at longitudes between UTM 0742254 to $0751912 \mathrm{E}$ and latitude $37 \mathrm{~N}$ 0619214 to $37 \mathrm{~N} 0629989$ and altitude between $1100 \mathrm{~m}$ and $1880 \mathrm{~m}$ (Figure 1).

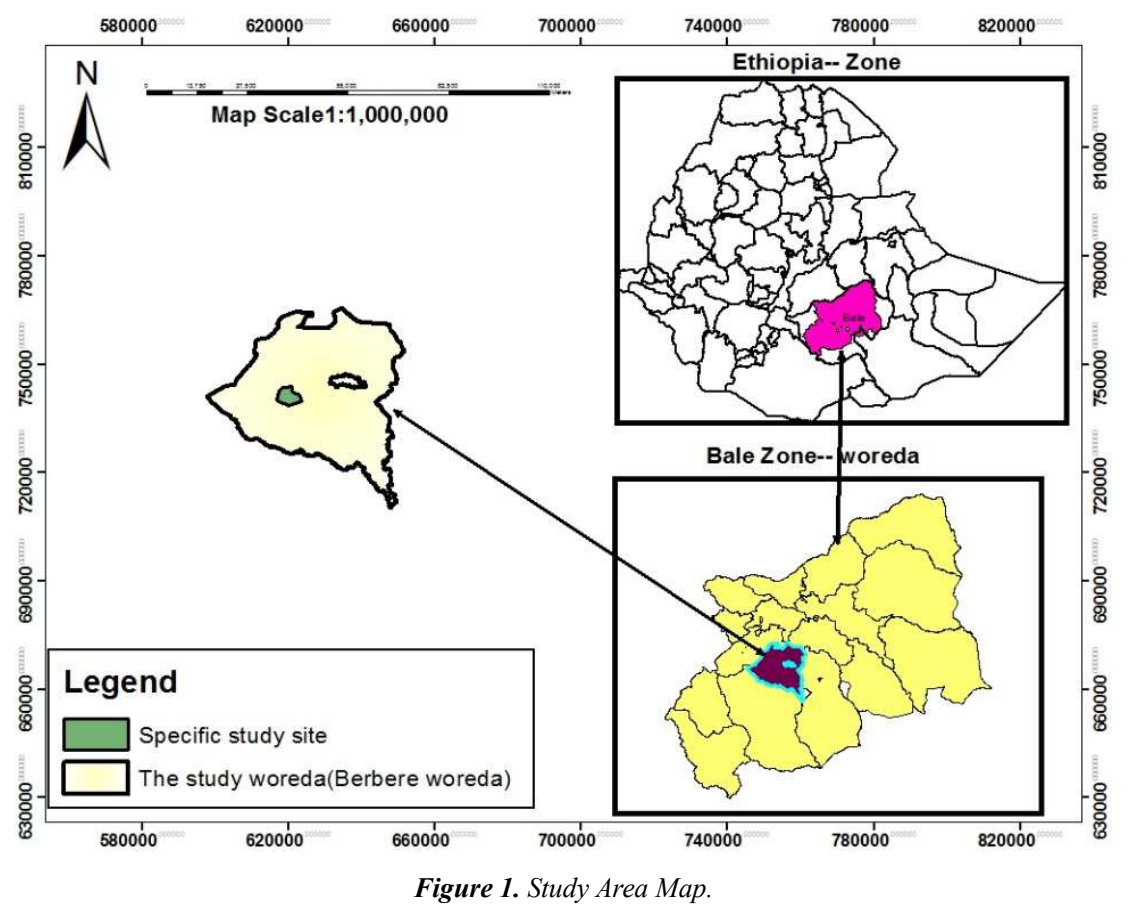

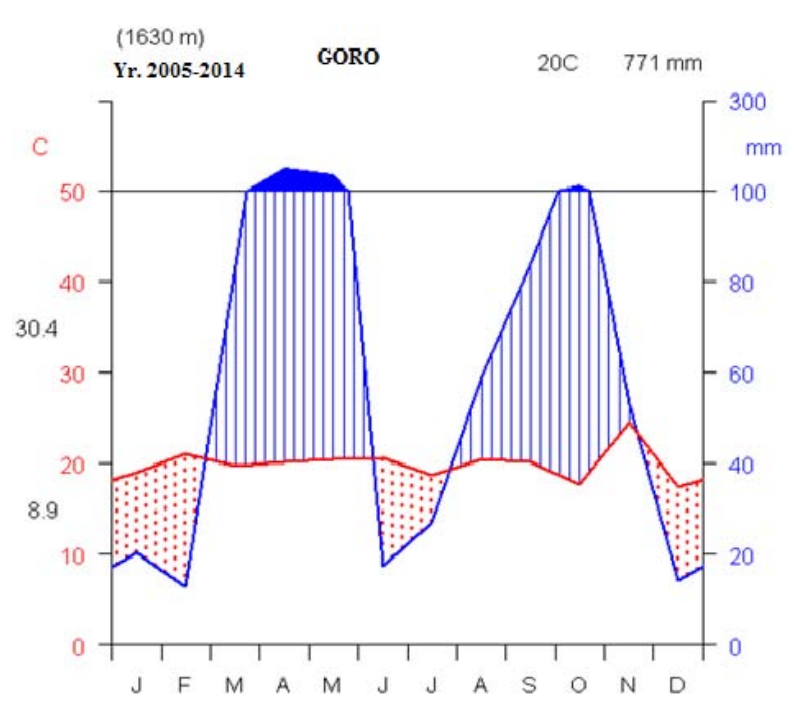

Figure 2. Climatic Diagram of Goro Meteorological Center Source: ([29]) (2005-2014).
Climate: The mean annual temperature is about $20.0^{\circ} \mathrm{C}$ and the mean annual minimum and maximum temperatures are $8.9^{\circ} \mathrm{C}$ and $30.44^{\circ} \mathrm{C}$ respectively. There is a slight difference in the temperature throughout the year. The hottest month is February with maximum temperature record $30.44^{\circ} \mathrm{C}$ and the coldest month is December with minimum temperature of $8.91^{\circ} \mathrm{C}$. The mean annual rainfall of the study area is 771 $\mathrm{mm}$. It is characterized by bimodal rainfall with the main rainy season occurring early March through May and the short rain late August through November. Since there is no meteorological center in the forest area and the nearby station were used for climatic data (Goro district, Goro meteorological center) (Figure 2).

\subsection{Sampling Design}

Systematic sampling design was used to collect vegetation data from the study site. By considering the edge effect nine parallel lines transects were systematically laid from the Hewas River (local name) then starting the first line transects randomly, and the rest systematically laid at $300 \mathrm{~m}$ apart 
from each other. On each of line transects eight quadrat were systematically laid which are $200 \mathrm{~m}$ apart from each other. To cover most of the representative of the forest, a total of seventy two quadrat size of $400 \mathrm{~m}^{2}(20 \mathrm{~m} \times 20 \mathrm{~m})$ for tree, shrub and lianas, and five $1 \mathrm{~m}^{2}(1 \mathrm{mx} 1 \mathrm{~m})$ for herbs one at each corner and one at the center of the main plot were laid following ([1], [13], [21], [35], [40]).

\subsection{Data Collection}

Data collection was conducted from October 05 to November 25, 2015. From the systematically designed quadrant along each transect a complete list of trees, shrubs, lianas, and herbs including vascular epiphytes were recorded. Species occurring within $10 \mathrm{~m}$ distance from the plots boundaries were also recorded as present for floristic composition but not use in the subsequent data analysis ([21]). Specimens of all vascular plant taxa were collected, pressed, dried for identification at the National Herbarium (ETH) of Ethiopia, Addis Ababa University. Some of the plants were identified in the field while most were identified at the National Herbarium specimens and using taxonomic key in the Flora of Ethiopia and Eritrea (FEE) ([17], [18]).

\subsection{Data Analysis}

Biological diversity was quantified by Shannon-Wiener diversity index. Species richness and evenness was computed to describe species diversity of the plant community types in the vegetation. Shannon-Wiener diversity index is the most popular measure of species diversity because it accounts both for species richness and evenness, and it is not affected by samples ([23]).

Based on the floristic composition data classification by means of hierarchical cluster analysis is the most common multivariate technique to analyze community data. Cluster analysis helps to group a set of observations (plots or vegetation samples) together based on their attributes or floristic similarities ([23], [27]). The Relative Euclidean Distance (RED) measures using Ward's method was used. The data matrix was contained the number of plots and number of species which was collected from the sample plots. Accordingly, a hierarchical cluster analysis was performed using PC-ORD for windows version 5.0 ([28]) to classify the vegetation into plant community types based on abundance data of the species in each quadrat. The data matrix contained 72 plots and 87 species collected from the sample plots. A species is considered as an indicator of the group when its indicator value is significantly higher at $\mathrm{p}<0.05$.

\section{Results and Discussion}

\subsection{Floristic Composition}

A total of 201 vascular plant species, belonging to 157 genera and 65 families were recorded from the vegetation. Fabacea was the most dominant family with 13 (8.28\%) genera and $23(11.44 \%)$ species. Astracceae was the second dominant family with $11(7.00 \%)$ genera and $13(6.48 \%)$ species. The third species-rich family was Euphorbiaceae with $8(5.09 \%)$ genera and $11(5.47 \%)$ species. The fourth and fifth species rich families were Acanthaceae and Rubiaceae with 7 (4.46\%) genera each and 10 (4.98\%) and 7 $(3.48 \%)$ species respectively (Table 1). One species identified at genus level (Lannea sp.). One hundred seventy seven species were collected within the 72 quadrats and the rest were collected outside the sample quadrats but within the forest and used to make the complete floristic list of the forest. The dominance of Fabaceae was reported from other vegetation studies in Ethiopia ([3], [9], [10], [13], [16], [32], [34]). This may imply that the environmental conditions in these areas are more favorable for this family.

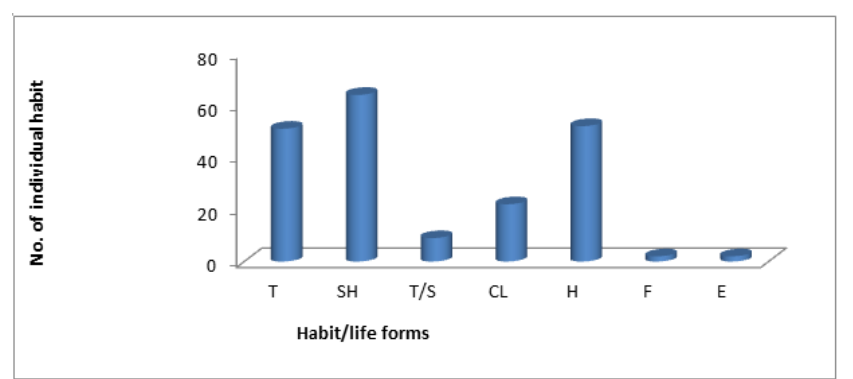

Figure 3. Number of Species Under Different Habit/Life Forms (T= Tree, $S H=S h r u b, T / S=$ Tree or Shrub, $C L=$ Climber/Liana, H=Herb, F=Fern and $E=$ Epiphyte).

Table 1. Families with Three and Above Corresponding Number of Genera and Species.

\begin{tabular}{lllll}
\hline \multirow{2}{*}{ Family } & Genera & \multicolumn{3}{l}{ Species } \\
\cline { 2 - 5 } & Number & \% & Number & \% \\
\hline Fabaceae & 13 & 8.28 & 23 & 11.44 \\
Astraceae & 11 & 7.00 & 13 & 6.48 \\
Euphorbiaceae & 8 & 5.09 & 11 & 5.47 \\
Acanthaceae & 7 & 4.46 & 10 & 4.97 \\
Rubiaceae & 7 & 4.46 & 7 & 3.48 \\
Lamiaceae & 6 & 3.82 & 8 & 3.98 \\
Poaceae & 6 & 3.82 & 6 & 2.98 \\
Solanaceae & 4 & 2.55 & 5 & 2.49 \\
Rhamnaceae & 4 & 2.55 & 4 & 1.99 \\
Malvaceae & 4 & 2.55 & 6 & 2.98 \\
Others & 87 & 55.41 & 108 & 53.73 \\
Total & 157 & 100 & 201 & 100 \\
\hline
\end{tabular}

Among the collected species were 64 (31.68\%) shrubs, 52 $(25.74 \%)$ herbs, $51(25.25 \%)$ trees, $9(4.46 \%)$ trees or shrubs, $22(10.89 \%)$ climbers/liana, $2(0.99 \%)$ epiphyte and 2 $(0.99 \%)$ ferns growth forms of species. Shrubs occupied the highest proportion followed by herbs and trees (Figure 3). Compared to other vegetation types in Ethiopia, the species richness of Berbere forest is greater than that of Denkoro forest (174 plant species, [4]), Dodola forest (113 plant species, [19]), Komto forest (180 plant species, [16]), Jibat forest (183 plant species, [8]), Belete forest (157 plant species, [13]) and Kimphe Lafa (130 plant species, [3]). But the species richness of Berbere forest was lower than that of Mana Angetu (211 plant species, [25]), Bale Mountains National Park (230 plant species, [40]), Bonga forest (243 
plant species [21]) and Nechisar National Park (208 plant species, [32]). The difference in species richness between these forests might arise from their altitudinal differences, climatic conditions and their vulnerability to anthropogenic activities.

\subsubsection{Commercially and Medicinally Important Plant Species}

Berbere forest like other forest contained 10 (41.67\%) out of 24 major commercial indigenous tree species (national priority tree species) reported by ([6], [11]). These tree species include Celtis africana, Cordia africana, Croton macrostachyus, Diospyros abyssinica, Pouteria adolfifriederici, Olea welwitschii, Olea hochsteri, Podocarpus falacatus, Syzygium guineense subsp. guineense and Warburgia ugandensis. As ([5], [7], [14], [15], [24], [25]) were identified and reported medicinal plants in different forest areas. Out of the total species 55 (27.36 5\%) species found in Berbere forest were medicinal plants. Out of these medicinal plant species the family Fabaceae was represented by the highest number of species ( 5 species, 9.09\%). This was followed by Euphorbiaceae, Lamiaceae, Myrsinaceae, and Solanaceae which had three species (5.45\%) each. Families Asteraceae, Acanthaceae, Celastraceae, Tiliaceae, Rosaceae, Rhamnaceae and Oleaceae were represented each by two species. This also indicates that the area consisted of considerable diversity of plant species. Therefore the study area forest is valuable for conservation of medicinal and commercial plant species.

\subsubsection{Endemic Plant Species}

There are a number of flowering plant species in the investigated forests that are endemic. Assessment of the conservation status of the woody taxa of Ethiopia and Eritrea is an important first step in planning conservation and sustainable use activities ([22], [36]). Based on the published Flora volumes and the list of species in the forest, the endemic species and the levels of threat on each taxon of Berbere forest are given in Table 2. It shows that 11 endemic species have been recorded from Berbere forest. This represented $5.47 \%$ of the total floristic composition of the forest. Of these, shrubs accounted for $45.5 \%$, herbs $27.7 \%$, trees $9.09 \%$, trees/shrubs $9.09 \%$ and climbers $9.09 \%$. The family with the most dominant of endemic species recorded within the forest was Fabaceae $(27.27 \%)$ followed by Astraceae and Lamiaceae each had $18.18 \%$. According to the IUCN criteria of level of threat, two species is have been under near threatened (NT) while nine species were found to be categorized as species of least concern (LC).

Table 2. Endemic Species of the Berbere Forest and Their IUCN Categories and Distributions (NT= Nearly Threatened, LC=Least Concern, VU= Vulnerable, $C R=$ Critically Endangered).

\begin{tabular}{|c|c|c|c|}
\hline Species & Family & IUCN category & Distribution in Ethiopia \\
\hline Acanthus sennii & Acanthaceae & NT & GD, GJ, WG, SU, HA, AR, BA, KF, GG, SD \\
\hline Aeollanthus abyssinicus & Lamiaceae & LC & WG, GJ, SU, BA, HA, IL, KF, GD, GG \\
\hline Crotolaria rosenii & Fabaceae & NT & $\mathrm{SU}, \mathrm{AR}, \mathrm{BA}, \mathrm{KF}, \mathrm{SD}$ \\
\hline Erythrina brucei & Fabaceae & LC & WU, WG, GJ, SU, BA, HA, IL, KF, GD, GG, SD \\
\hline Leucas abyssinica & Lamaciae & LC & TU, GD, GG, SD, BA \\
\hline Lippia adoensis & Verbenaceae & LC & TU, GJ, SU, AR, HA, KF, GG \\
\hline Mikaniopsis clematoides & Asteraceae & LC & TU, GD, SU, HA, BA, AR, KF \\
\hline Millettia ferruginea & Fabaceae & LC & TU, GD, GJ, SU, WG, HA, IL \\
\hline Solanum marginatum & Solanaceae & LC & BA, TU, GD, SU, GJ, GG, AR, SD, HA \\
\hline Urtica simensis & Urticaceae & LC & TU, GD, GJ, SU, AR, BA, SD \\
\hline Vernonia leopoldi & Astraceae & LC & TU, GD, GJ, SU, WG, KF, HA \\
\hline
\end{tabular}

*SD=Sidama, AR=Arsi, BA=Bale, GD=Gonder, WU=Wollo, GJ=Gojam, HA=Harage, EW=Eritrea West, KF=Kefa, IL=Illubabor, GG=Gamo Gofa, $\mathrm{TU}=$ Tigray, $\mathrm{SU}=$ Shewa (adopted from Flora of Ethiopia and Eritrea).

\subsection{Vegetation Classification}

Vegetation classification is a powerful tool employed for several purposes, including: efficient communication, data reduction and synthesis, interpretation, and land management and planning. It also provides one way of summarizing our knowledge of vegetation patterns ([20]). Hence in Berbere forest three plant community types (clusters) were identified at $25 \%$ similarity level from the hierarchal cluster analysis using PC-ORD version 5 computer programme (Figure 4).

Community names were given after one or two species that had higher indicator values. The latter distinguished the community by their high relative abundance and relative frequency. In all observed plant communities, species with higher indicator values are those that were easily observed repeating themselves in associations. In the Table 3 the bold values indicate significant indicator value $\left(\mathrm{P}^{*}<0.05\right)$ in each group. Thus, the identified groups are more or less coninciding with the natural associations that anyone can observe while crossing through the forest. The three plant communities identified were: Terminalia brownie-Psydrax schimperiana (Community type 1), Warburgia ugandensisPodocarpus falcatus (Community type 2), and Euclea racemosa subsp. schimperi-Combretum molle (Community type 3 ). 


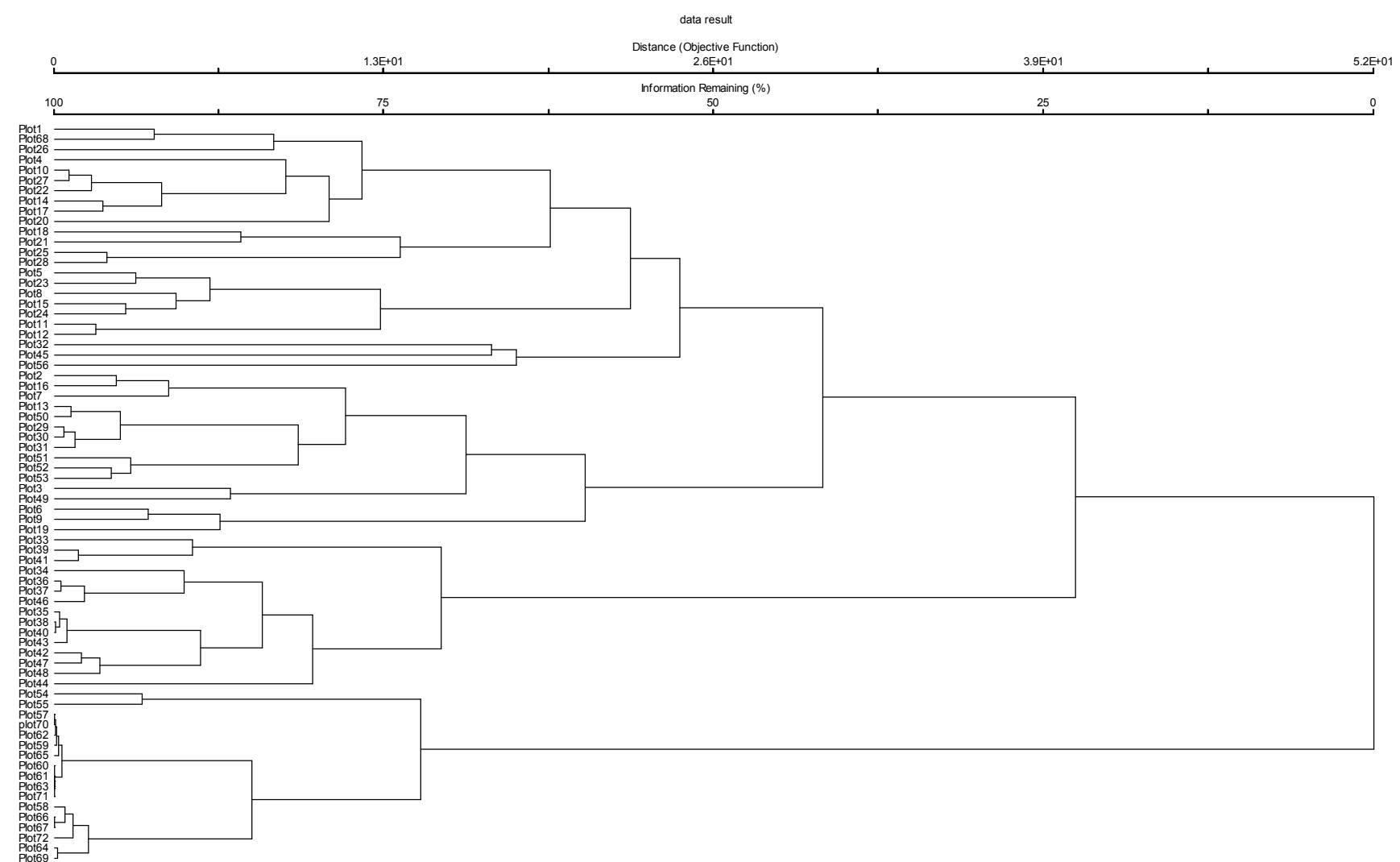

Figure 4. Dendrogram of the Vegetation Data Obtained from Hierarchical Cluster Analysis of Berbere Forest Using Ward's Method and Euclidean Distance. The Level of Grouping was based on 25\% Information Remaining (Community I plots 1, 2, 3, 4, 5, 6, 7, 8, 9, 10, 11, 12, 13, 14, 15, 16, 17, 18, 19, 20, 21, 22, $23,24,25,26,27,28,29,30,31,32,45,49,50,51,52,53,56$ and 68 , Community II plots 33, 34, 35, 36, 37, 38, 39, 40, 41, 42, 43, 44, 46, 47 and 48, Community III plots 54, 55, 57, 58, 59, 60, 61, 62, 63, 64, 65, 66, 67, 69, 70, 71 and 72).

Table 3. Indicator Species for Each Three Community and the Monte Carlo Test $\left(P^{*}\right)$ of the Significance Observed for Each Species. Bold Values Indicate Indicator Species $\left(P^{*}<0.05\right)$.

\begin{tabular}{lllll}
\hline \multirow{2}{*}{ Species name } & \multicolumn{3}{c}{ Community } & \multirow{2}{*}{ * } \\
\cline { 2 - 4 } & I & II & III & \\
\hline Terminalia brownii & 87.7 & 0 & 0 & 0.0150 \\
Psydrax schimperiana & 81.5 & 7.7 & 25.0 & 0.0166 \\
Caesalpinia volkensii & 62.8 & 0 & 0 & 0.0100 \\
Acacia brevispica & 59.4 & 0 & 0 & 0.0076 \\
Schrebera alata & 58.7 & 0 & 0 & 0.0312 \\
Warburgia ugandensis & 40.4 & 61.9 & 49.5 & 0.0054 \\
Podocarpus falcatus & 3.1 & 58.9 & 0 & 0.0325 \\
Celtis africana & 30.4 & 40.0 & 30.8 & 0.0235 \\
Euclea racemosa subsp. schimperi & 18.7 & 0 & 100.0 & 0.0074 \\
Combretum molle & 40.9 & 0 & 97.4 & 0.0074 \\
Filicium decipiens & 30.8 & 35.9 & 88.2 & 0.0376 \\
Diospyros abyssinica & 25.4 & 48.7 & 69.8 & 0.0074 \\
Olinia rochetiana & 12.5 & 46.2 & 50.0 & 0.0438 \\
\hline
\end{tabular}

\subsubsection{Terminalia Brownii-Psydrax Schimperiana Community Type}

This community type was represented by 40 quadrats $(1.60$ ha) and 49 species. This community was found betwween 1170 - $1536 \mathrm{~m}$ a.s.l altitudinal ranges. The associated trees, shrubs and tree/shrub of this plant community were: Acacia abyssinica, Acacia brevispica, Acacia bussei, Acacia mellifera, Acacia seyal, Berchemia discolor, Buddleja polystachya, Caesalpinia volkensii, Celtis africana, Combretum aculeatum, Combretum collinum subsp.
Binderianum, Combretum molle, Cordia africana, Croton macrostachyus, Dichrostachys cinerea, Diospyros abysinica, is, Ficus vasta, Filicium decipiens, Gardenia ternifolia, Grewia bicolor, Grewia ferruginea, Lannea rivae, Lannea triphylla, Maesa lanceolata, Mimusops kummel, Podocarpus falcatus, Psydrax schimperiana, Rhus natalensis, Rhus ruspolii, Warburgia ugandensis and Ziziphus spina-christi. The dominant herbs of the community are Carduus nyassanus, Partherium, sida alba, Perotis patens, Barleria ventricose, Sida urens, Commelina africana, achyranthes aspera, Datura stramonium. The common climbers are Embellia schimperi, Gouania longispicta, Clematis simensis and Secamone punctulata. Tree cutting for construction and charcoal making was more prevalent in the vegetation where this community occurs. It was also noticed that large hectares of the vegetation was being converted to agricultural land. Human settlement and livestock population appear to have influenced several aspects of the vegetation such as regeneration and recruitment. Out of fourteen tree species which have no seedling or saplings in the forest twelve tree species were found in this community.

\subsubsection{Warburgia Ugandensis-podocarpus Falcatus Community Type}

This community had indicator species like Podocarpus falcatus, Warburgia ugandensis and Celtis africana. This community type were located between 1449-1563 m a.s.l. 
and comprised of 15 quadrats ( $0.60 \mathrm{ha})$ and 18 woody plant species. Podocarpus falcatus, Olea capensis subsp. hochstetteri, Olea capensis subsp. Macrocarpa and Pouteria adolfi-friederici were the dominant tree species. The main associated characteristic tree and shrub species to this community Bersama abyssinica, Mimusops kummel, Oncoba spinosa, Celtis africana, Maesa lanceolata, Psydrax schimperiana, Cassipourea malosana Buddleja polystachya and Olinia rochetiana. The common climbers were Mikaniopsis clematoides, lagenaria sicersria, Vigna vexillata and Nespostylis holosericeae. This community was also under great pressure of human activities like agricultural exapansion, ilegal settlement and over grazing.

\subsubsection{Euclea Racemosa Subsp. Schimperi-combretum Molle Community Type}

This community type is distributed between the altitudinal range of 1221-1267 $\mathrm{m}$ a.s.l and contains 17 quadrats (0.68 ha) and 20 species. The most common associated characteristic tree and shrub species to this community included Diospyros abyssinica, Olinia rochetiana, Celtis africana, Combretum molle, Tamarindus indica, Croton macrostachyus and Ficus thonningii. The common herbs were Triumfetta pentandra, Triumfetta rhombodea, Urtica simensis, Gnidia stenophylla and Datura stramonium. The common climbers in this community were Urera hypselodendrron, Cissus quadrangularis, Celmatis simensis,
Jasminum abssinicum and Embellia schimperi.

\subsection{Species Richness, Diversity and Evenness of the Plant Community Type}

A combination of the number of species and their relative abundance defines species diversity. The values of species diversity depend upon levels of species richness and evenness ([26]). The Shannon - Wiener diversity index (H') was computed for each plant community types. The different values of $H^{\prime}$ for the communities reflect the difference in their species richness and evenness. The minimum value of $H^{\prime}$ is 0 , which a value for a community with a single species and increases as species rihness and evenness increases. Based on the outcome of the Shannon-Weiner diversity index analysis, community type I had the highest species diversity and evenness followed by communities II and III. Community type I took the the first rank with similar species richness. Community type III was the least in its species diversity and evennes (Table 4). The variability of the community types might be probaly due to difference in their species composition, number of plots and their altitude difference, level of distrubance involved (like selective cutting for wood, charcoal and construction). In addition agricultural exapansion and ilegal settlement, and over grazing also the major problem of the area.

Table 4. Shannon-Wiener Diversity Index.

\begin{tabular}{llllll}
\hline Communities & Average altitude (m a.s.I) & Species Richness & Diversity Index (H') & H'max (Ln S) & Evenness (H'/H'max) \\
\hline I & 1216.55 & 49 & 2.95 & 3.89 & 0.76 \\
II & 1508.20 & 18 & 2.02 & 2.89 & 0.69 \\
III & 1255.24 & 20 & 1.51 & 2.99 & 0.52 \\
\hline
\end{tabular}

\subsection{Similarity Coefficient Among Community Types}

Sorenson's similarity coefficient was used to determine the similarities among plant communities. Accordingly, communities I and III had the highest similarity ratio (Table 5). This could be associated to slope, aspect, the anthropogenic and other environmental factors such as soil type and properties which were not considered in this study. The least similarity was exhibited by communities II and III. This might be because of variation in altitude, slope, aspect and other environmental factors.

Table 5. Sorensen Similarity Coefficient Among Three Community Types.

\begin{tabular}{llll}
\hline Communities & I & II & III \\
\hline I & 1 & & \\
II & 0.32 & 1 & \\
III & 0.43 & 0.31 & 1 \\
\hline
\end{tabular}

\section{Conclusion and Recommendations}

Berbere forest is a part of Goro Belle forest hosting many endimic species. This forest is ecologically, socially, commercial and economically very important for livelhood of the area.
The results of this study indicated that the presence of relatively high species diversity, which are 201 species, 157 genera and 65 families. Fabaceae was found to be the most dominant family followed by Astraceae, Euphorbiaceae, Acanthaceae and Rubiaceae. Shrubs and herbs were the dominant growth forms. More similarity coefficient was observed between community types I and III, and between community type II and III and less similarity was observed between community type I and community type II. The variation in species composition and diversity among communities could be associated to different factors, such as altitude, anthropogenic impacts, soil properties, slope and aspect. From the total species recorded 11 (5.47\%) species are endemic listed in the IUCN red data list category. The following recommendations were made;further study on the conservation challenges in the area; raise public awareness on the value of forest genetic resource; promote the sustainable use of the forest and its products, ethno botanical studies and exploration of indigenous knowledge on the diverse uses of plants should be carried out and government should critical take an action on managing the forests jointly with the local community as well as creating other income generating activity and alternative sources of energy. 


\section{Conflict of Interests}

The authors declare that they have no competing interests.

\section{References}

[1] Adamu, H. W., Bekele, T. \& Dalle, G. (2012). Floristic diversity, regeneration status and vegetation structure of woodlands in Metema area, Amhara National Regional State, North-western Ethiopia. Journal of Forestry Research, 23(3): 391-398.

[2] Addo-Fordjour, P., Obeng, S., Anning, A. and Addo, M. (2009). Floristic composition, structure and natural regeneration in a moist semi- deciduous forest following anthropogenic disturbances and plant invasion. International Journal of Biodiversity Conservation, 1: 21-37.

[3] Aliyi, K., Hundera, K. \& Dalle, G. (2015). Floristic Composition, Vegetation Structure and Regeneration Status of Kimphe Lafa Natural Forest, Oromia Regional State, West Arsi, Ethiopia. Research \& Reviews: Journal of Life Sciences. 5(1): 19-32.

[4] Ayalew, A., Bekele, T. \& Demissew, S. (2006). The Undifferentiated afromontane forest of Denkoro in the central highland of Ethiopia: A floristic and Structural Analysis. Ethiopian Journal of Science, 29(1): 45-56.

[5] Bekele, D., Asfaw, Z., Petros, B. \& Tekie, H. (2012). Ethnobotanical study of plants used for protection against insect bite and for the treatment of livestock health problems in rural areas of Akaki District, Eastern Shewa, Ethiopia. Top class Journal of Herbal Medicine, 1(2): 12-24.

[6] Bekele, M. \& Berhanu, L. (2001). State Forest Genetic Resources in Ethiopia. Sub-Regional workshop FAO/IPGRI/ICRAF on the conservation, management, sustainable utilization and enhancement of forest genetic resources in Sahelian and North-Sudanian Africa (Ouagadougou, Burkina Faso, 22-24 September 1998). Forest Genetic Resources Working Papers, Working Paper Forestry Department, FAO, Rome.

[7] Belayneh, A., Asfaw, Z., Demissew, S. \& Bussa, N. (2012). Medicinal plants potential and use by pastoral and agropastoral communities in Erer Valley of Babile Wereda, Eastern Ethiopia. Journal of Ethnobiology and Ethnomedicine, 8: 42.

[8] Burju, T., Hundera, K. \& Kelbessa, E. (2013). Floristic Composition and Structural Analysis of Jibat Humid Afromontane Forest, West Shewa Zone, Oromia National Regional State, Ethiopia. Ethiopian Journal of Education and Science, 8 (2): 11-33.

[9] Dibaba, A, Soromessa, T, Kelbessa, E. \& Tilahun, A. (2014). Diversity, Structure and Regeneration Status of the Woodland and Riverine Vegetation of Sire Beggo in Gololcha District, Eastern Ethiopia. Momona Ethiopian Journal of Science, 6(1): 70-96.

[10] Didita, M., Nemomissa, S. \& Woldemariam, T. (2010). Floristic and structural analysis of the woodland vegetation around Dello Menna, Southeast Ethiopia. Journal of Forestry Research, 21: 395-408.

[11] EFAP (Ethiopian Forestry Action Program). (1994). Ethiopian Forestry Action Program (Vol. 2). Addis Ababa: The Challenge for Development. Ministry of Natural Resources
Development and Environmental Protection, Pp. 45-150.

[12] EWNHS (Ethiopian Wildlife and Natural History Society) (1996). Important Birds Areas of Ethiopia. A First Inventory. EWNHS, Addis Ababa.

[13] Gebrehiwot, K. \& Hundera, K. (2014). Species composition, Plant Community structure and Natural regeneration status of Belete Moist Evergreen Montane Forest, Oromia Regional state, Southwestern Ethiopia. Momona Ethiopian Journal of Science, 6(1): 97-101.

[14] Gebrezgabiher, G., Kalayou, S. \& Sahle, S. (2013). An ethnoveterinary survey of medicinal plants in woredas of Tigray region, Northern Ethiopia. International Journal of Biodiversity and Conservation, 5(2): 89-97.

[15] Gidaya, M., Asfaw, Z. \& Woldu, Z. (2009). Medicinal plants of the Meinit ethnic group of Ethiopia: An ethnobotanical study. Journal of Ethnopharmacology, Pp. 1-9.

[16] Gurmessa, F., Soromessa, T. \& Kelbessa, E. (2013). Floristic composition and community analysis of Komto Afromotane moist forest, East Wollega zone, West Ethiopia. Journal of Science, Technology and arts Research, 2: 58-69.

[17] Hedberg, I., Friis, I. \& Person, E. (eds.). (2009). General Part and Index to Vol 1-7. Flora of Ethiopia and Eritrea Volume 8. The National Herbarium, Addis Ababa, Ethiopia and Uppsala, Sweden.

[18] Hedberge, I., Edwards, S. \& Nemomissa, S. (eds.) (2003). Flora of Ethiopia and Eriterea, volume 4, Apiaceae to Dipsacaceae. The National Herbrium, Addis Ababa University, Addis Ababa and Department of Systematic Botany, Uppsala University, Uppsala.

[19] Hundera, K., Bekele, T. \& Kelbessa, E. (2007). Floristic and phytogeographic synopsis of a dry afromontane coniferous forest in Bale Mountains, Ethiopia: Implication to biodiversity conservation. SINET: Ethiopian Journal of Science, 30: 1-12.

[20] Jennings, M., Jennings, O., Glenn-Lewin, D., Peet, R., FaberLangendoen, D., Grossman, D., Damman, G., Barbour, M., Pfister, R., Walker, M., Talbot, S., Walker, J., Hartshorn, G., Waggoner, G., Abrams, M., Hill, A., Roberts, D. \& Tart, D. (2003). Guidelines for describing Associations and Alliances of the U.S. National vegetation classification Panel.

[21] Kelbessa, E. \& Soromess, T. (2008). Interfaces of regeneration, structure, diversity and uses of some plant species in Bonga Forest: A reservoir for wild coffee gene pool. SINET: Ethiopian Journal of Science, 31(2): 121-134.

[22] Kelbessa, E., Demissew, S, Woldu, Z. \& Edwards, S. (1992). Some threatened Endemic Plants of Ethiopia. NAPRECA Monograph, 2: 35-55.

[23] Kent, M. \& Coker, R. (1992). Vegetation Description and Analysis: A practical approach. John Wiley and Sons, New York. Pp. 363.

[24] Lulekal, E., Asfaw, Z., Kelbessa, E. \& Patrick V. D. (2013). Ethnomedicinal study of plants used for human ailments in Ankober District, North Shewa Zone, Amhara Region, Ethiopia. Journal of Ethnobiology and Ethnomedicine, 9: 63.

[25] Lulekal, E., Kelbessa, E., Bekele, T. \& Yineger, H. (2008). Plant Species Composition and Structure of the Mana Angetu Moist Montane Forest, South-Eastern Ethiopia. Journal of East African Natural History, 97(2): 165-185. 
[26] Manuel, C. \& Molles, J. (2007). Ecology concepts and applications. McGraw-Hill, Inc., New York.

[27] Mccune, B. \& Grace, J. B. (2002). Analysis of Ecological Communities. Mj M Software design, USA, Gleneden Beach, Oregon. Pp. 304.

[28] Mccune, B. \& Mefford, M. J. (1999). PC-ORD. Multivariate Analysis of Ecological Data. Version 5.0. MjM software, Gleneden Beach, Oregon.

[29] National Metrological Service Agency, Robe Branch (2015). Data of Rainfall and Temperature of ten years (2003-2014).

[30] Senbata, F. (2006). Biodiversity and Ecology of Afromontane Rainforests with Wild Coffea arabica L. Populations in Ethiopia. Ecology and Development Series No. 38. Center for Development Research, University of Bonn.

[31] Senbeta, F. \& Tektay, D. (2003). Diversity, community types and population structure of woody plants in Kimphe Forest, a virgin Nature Reserve in Southern Ethiopia. Ethiopian Journal of Biological Sciences, 2: 169-187.

[32] Shimelse, S., Bekele, T. \& Mengistu, A. (2010). Floristic Diversity and Structure of Nechisar National Park, Ethiopia. Journal of the Drylands, 3(1): 165-180.

[33] Teketay, D. (1992). Human impact on a natural montane forest in Southeastern Ethiopia. Mount Res dev, 12: 393-400.

[34] Tesfaye, G., Bekele, T. \& Demissew, S. (2008). Dryland woody vegetation along an altitudinal gradient on the eastern escarpment of Welo, Ethiopia. Ethiopian Journal of Science, 31: 43-54.

[35] Tiwari, K. P. G., Tadele, K., Aramde, F. \& Tiwari, S. C. (2010). Community Structure and Regeneration Potential of Shorea robusta Forest in Subtropical Submontane Zone of Garhwal Himalaya, India. Nature and Science, 8: 70-74.

[36] Vivero, J. L., Kelbessa, E. \& Demissew, S. (2005). The Red list of Endemic Trees and Shrubs of Ethiopia and Eritrea. Fauna and Flora International, Cambridge. Pp. 23.

[37] Williams, S. D., Vivero, J. L., Spawls, S., Shimelis, A. \& Kelbessa, E. (2005). Ethiopian Highlands. In: Mittermeier, R. (ed) Hotspots revisited. Conservation International and Cemex.

[38] Woldu, Z. (2008). The Population, Health and Environment Nexus, The need for integration and networking. A background paper for the establishment and launching of PHE. Addis Ababa University. Pp. 34.

[39] Yemishaw, Y. (2002). Legal Forest aspects. In: State of Forests and Forestry research in Ethiopia. (Demel Teketay and Tesfaye Bekele, eds). I-TOO working paper No. 1: 7-12 Germany.

[40] Yineger, H., Kelbessa, E, Bekele T. \& Lulekal, E. (2008). Floristic Composition and Structure of the Dry Afromontane Forest at Bale Mountains National Park, Ethiopia. Ethiopian Journal of Science, 31(2): 103-120. 